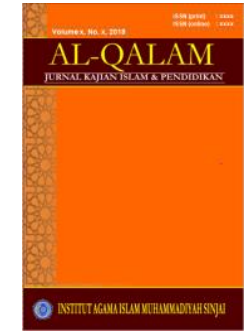

AL-QALAM

Jurnal Kajian Islam \& Pendidikan

Volume 11, No. 1, 2019

ISSN (print) : 1858-4152

ISSN (online) : 2715-5684

Homepage : http://journal.iaimsinjai.ac.id/index.php/al-qalam

\title{
ISLAM DAN ILMU PENGETAHUAN
}

\author{
Suriyati ${ }^{1}$, \\ ${ }^{1}$ Institut Agama Islam Muhammadiyah Sinjai, Jln Sultan Hasanuddin No. 20, Sinjai, Sulawesi Selatan \\ Suriyati.iaim@gmail.com
}

\begin{abstract}
Abstrak
Perkembangan ilmu pada masa klasik sangat maju karena prinsip-prinsip semua ilmu terdapat dalam Alquran dan Hadis; pencarian ilmu dalam segi apa pun pada akhirnya akan bermuara pada penegasan Tauhid. Tapi pada masa pemerintahan Ali Fitnah Besar menimpa kaum muslim memunculkan paham teologis, namun ada yang tidak melibatkan diri.dan merea adalah moyang Ahlussunnah Waljamaa'ah, kemudian masuklah unsur-unsur dari luar ke dalam Islam, seperti unsurunsur budaya Perso-Semitik (Zoroastrianisme- khususnya Mazdaisme, serta Yahudi dan Kristen) dan budaya Hellenisme. Pada masa kejayaan 3 dinasti besar Dinasti Umayyah dan Dinasti Abbasiyah, Fatimiyah Ilmu berkembang sangat maju dan pesat. Kemajuan ini membawa, Islam pada masa keemasannya, dengan kelahiran tokoh ilmuwan muslim di segala bidang. Masa keruntuhan tradisi keilmuan dalam islam terjadi karena: a. Transfer filsafat-filsafat India, Persia dan Yunani, $b$. Adanya manipulasi ajaran Islam oleh orang-orang yang membenci Islam, c. Diabaikannya bahasa Arab menebakan sulit berijtihad, $d$. Serangan gelombang missionaris, dan serangan (orientalis) Serangan gelombang missionaris, dan serangan (orientalis). Ilmu pengetahuan beralih ke dunia barat: a. adanya pelajar-pelajar barat yang belajar di duinia Islam, $b$. penterjemahan besar-besaran buku ke berbagai bahasa, c. perampasan ilmu-ilmu Islam dengan jalan perang salib.
\end{abstract}

Kata Kunci : Islam, Ilmu Pengetahuan

\section{Pendahuluan}

Sejak awal kelahirannya, Islam sudah memberikan penghargaan yang begitu besar kepada, ilmu. Sebagaimana sudah diketahui, bahwa Nabi Muhammad saw. ketika diutus oleh Allah sebagai rasul, hidup dalam masyarakat yang terbelakang, dimana paganisme tumbuh menjadi sebuah identitas yang melekat pada, masyarakat Arab masa itu. Kemudian Islam datang menawarkan cahaya penerang, yang mengubah masyarakat Arab jahiliyah menjadi masyarakat yang berilmu dan beradab.

Kalau dilacak akar sejarahnya, pandangan Islam tentang pentingnya ilmu,tumbuh bersamaan dengan munculnya Islam itu sendiri. Ketika Rasulullah saw.menerima, wahyu pertama, yang mulamula diperintahkan kepadanya adalah "membaca"(Bahtiar, 2006: 32). Jibril memerintahkan Muhammad: "Bacalah dengan (menyebut) nama Tuhan-mu yang menciptakan" QS. al-'Alaq (96): 1 (Departemen Agama RI, : 597).

Perintah ini tidak hanya sekali diucapkan Jibril tetapi berulang-ulang sampai Nabi dapat menerima wahyu tersebut. Dari kata iqra inilah kemudian lahir aneka makna seperti menyampaikan, menelaah, mendalami, meneliti, mengetahui ciri sesuatu, dan membaca teks baik yang tertulis maupun tidak (Shihab, 2001: 433). Wahyu pertama, itu menghendaki umat Islam untuk senantiasa membaca dengan dilandasi bismi Rabbik, dalam arti hasil bacaan itu nantinya dapat bermanfaat untuk kemanusiaan.

Selanjutnya, ada juga. ayat lain yang menyatakan:

"Katakanlah: apakah sama orang-orang yang mengetahui (berilmu) dengan orang-orang yang tidak mengetahui?, sesungguhnya (hanya) orang-orang yang berakallah yang dapat menerima. pelaiaran" QS. (al-Zumar (39): 9 (Departemen Agama RI, : 459). 


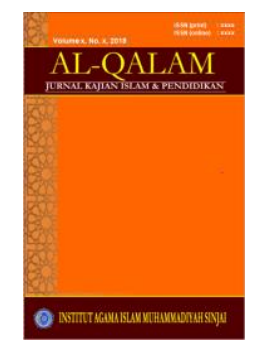

AL-QALAM

Jurnal Kajian Islam \& Pendidikan

Volume 11, No. 1, 2019

ISSN (print) : 1858-4152

ISSN (online) : 2715-5684

Homepage : http://journal.iaimsinjai.ac.id/index.php/al-qalam

Selain ayat-ayat tersebut di atas, ada juga hadis Rasulullah yang menekankan wajibnya mencari ilmu, antara lain: "Menuntut Ilmu wajib atas tiap-tiap muslim"(11R. Ibnu 'Abdil Bar.Dari Anas) (alHasyimi, t.t.: 93). Dengan demikian, Alquran dan Hadis kemudian dijadikan sebagai sumber ilmu yang dikembangkan oleh urnat Islam dalam spektrum yang seluas-luasnya. Lebih lagi, kedua sumber pokok Islam ini memainkan peran ganda dalam penciptaan dan pengembangan ilmu-ilmu. Peran itu adalah:

Pertama, prinsip-prinsip semua ilmu dipandang kaum Muslimin terdapat dalam Alquran. Dan sejauh pemahaman terhadap Alquran, terdapat pula penafsiran.,yang bersifat esoteris terhadap kitab suci ini, yang memungkinkan tidak hanya pengungkapan misteri-misteri yang dikandungnya tetapi juga pencarian makna secara lebih mendalarn, yang berguna untuk pembangunan paradigma ilmu.

Kedua, Alquran dan Hadis menciptakan iklim yang kondusif bagi pengembangan ilmu dengan menekankan kebajikan dan keutamaan menuntut ihnu; pencarian ilmu dalam segi apa pun pada akhirnya akan bermuara pada penegasan Tauhid. Karena itu, seluruh metafisika dan kosmologi yang lahir dari kandungan Alquran dan Sunnah merupakan dasar pernbangunan dan pengembangan ilmu Islam. Singkatnya, Alqur'an dan Sunnah menciptakan atmosfir khas yang mendorong aktivifas intelektual dalarn konformitas (Azra, 2001: 13).

Dengan semangat Islam yang besar menuntut ilmu, menjadikan kaum muslim memburu ilmuilmu pengetahuan dan berbagai negara dan peradaban dunia diantaranya ilmu pengetahuan Yunani dan India, namun bukan berarti ilmu pengetahuan Islam belum bekembang sebelum pengadopsian ilmu dari dunia luar. Setelah berinteraksi ilmu islam dengan ilmu pengetahuan yang lain maka munculah ilmuwan-ilmuwan baru dari kalangan kaum muslim. seperd Al-Kindi, Al-Farabi, Ibnu Sina, Ibnu Rusyd dan yang lainnya. Seiring dengan perkembangan ilmu penetahuan dan munculnya ilmuwan menjadikan peradaban Islam menjadi pusat peradaban terutama, di masa pemerintahan Daulah Umaiyah, Abbasiyah, dan Fatimiyah. Peradaban inilah yang menjadi cikal bakal perkembangan renaisans di dunia barat.

\section{Metode}

Berisi jenis penelitian, waktu dan tempat penelitian, target/sasaran, subjek penelitian, prosedur, instrumen dan teknik analisis data serta hal-hal lain yang berkait dengan cara penelitiannya. target/sasaran, subjek penelitian, prosedur, data dan instrumen, dan teknik pengumpulan data, serta teknik analisis data serta hal-hal lain yang berkait dengan cara penelitiannya dapat ditulis dalam subsubbab, dengan sub-subheading. Sub-subjudul tidak perlu diberi notasi, namun ditulis dengan huruf kecil berawalkan huruf kapital, TNR-11 unbold, rata kiri.

Khususnya untuk penelitian kualitatif, waktu dan tempat penelitian perlu dituliskan secara jelas (untuk penelitian kuantitatif, juga perlu). Target/subjek penelitian (untuk penelitian kualitatif) atau populasi-sampel (untuk penelitian kuantitatif) perlu diurai dengan jelas dalam bagian ini. Perlu juga dituliskan teknik memperoleh subjek (penelitian kualitatif) dan atau teknik samplingnya (penelitian kuantitatif).

\subsection{Addsd}

Prosedur perlu dijabarkan menurut tipe penelitiannya. Bagaimana penelitian dilakukan dan data akan diperoleh, perlu diuraikan dalam bagian ini. Untuk penelitian eksperimental, jenis rancangan (experimental design) yang digunakan sebaiknya dituliskan di bagian ini. Macam data, bagaimana data dikumpulkan, dengan instrumen yang mana data dikumpulkan, dan bagaimana teknis pengumpulannya, perlu diuraikan secara jelas dalam bagian ini.

\section{$2.2 \mathrm{Xss}$}

Bagaimana memaknakan data yang diperoleh, kaitannya dengan permasalahan dan tujuan penelitian, perlu dijabarkan dangan jelas. Catatan: Sub-subbab bisa berbeda, menurut jenis atau 
pendekatan penelitian yang digunakan. Jika ada prosedur atau langkah yang sifatnya sekuensial, jika subbab bukan merupakan judul maka hanya menggunakan huruf. Misalnya sebagai berikut:
a. Poin Satu
b. Poin dua
c. Poin tiga
d. Dan seterusnya.

\section{Hasil dan Pembahasan}

\subsection{Penyampaian Ilmu dan Filsafat Yunani ke Dunia Islam}

Pengalihan pengetahuan ilmiah dan Filsafat Yunani ke dunia Islam, dan penyempian serta pengintegrasian. pengetahuan itu oleh umat Islam, merupakan sebuah catatan sejarah yang unik. Dalam sejarah peradaban manusia, amat jarang ditemukan suatu kebudayaan asing dapat diterima sedemikian rupa oleh kebudayaan lain, yang kemudian menjadikannya landasan bagi perkembangan intelektual dan pemahaman filosofisnya (Bahtiar, 2006: 3).

Dalam perjalanan ilmu dan juga filsafat di dunia, Islam, pada dasamya. terdapat upaya rekonsiliasi dalam arti mendekatkan dan mempertemukan dua pandangan yang berbeda, bahkan seringkali ekstrim antara pandangan filsafat Yunani, seperti filsafat Plato dan Aristoteles, dengan pandangan keagamaan dalam Islam yang seringkah menimbulkan benturan-benturan. Sebagai contoh kongkret dapat disebutkan bahwa Plato dan Aristoteles telah memberikan pengaruh yang besar pada mazhab-mazhab Islam, khususnya mazhab eklektisisme. Al-Farabi, alam hal ini, memiliki sikap yang jeias karena ia percaya pada kesatuan filsafat dan bahwa tokoh-tokoh filsafat harus bersepakat di antara mereka sepanjang yang menjadi tujuan mereka adalah kebenaran. Bahkan bisa dikatakan para filosof Muslim mulai dari Al-Kindi sarnpai Ibn Rusyd terlibat dalam upaya rekonsiliasi tersebut, dengan cara mengemukakan pandangan-pandangan yang relatif baru dan menarik. Usaha-usaha mereka pada gilirannya menjadi alat dalam penyebaran filsafat dan penetrasinya ke dalam studi-studi keislaman lainnya, dan tak diragukan,lagi upaya rekonsiliasi oleh para filosof Muslim ini menghasilkan aktivitas dan ikatan yang kuat antara. filsafat Arab dan filsafat Yunani (Bahtiar, 1986: 118-119).

Selanjutnya, ketika berbicara tentang proses penyampaian ilmu. dan filsafat Yunani ke dunia Islam, kita harus melihat sisi lain yang juga. menunjang keberhasilan Islam dalam menemukan dan mengembangkan ilmu pengetahuan. Sisi lain itu adalah aktivitas pentejermahan. Menurut C. A. Qadir, proses penterjemahan penafsiran buku buku Yunani di negeri-negeri Arab dimulai jauh sebelum lahirnya agama. Islam atau penaklukan Timur Dekat oleh bangsa Arab pada tahun $641 \mathrm{M}$. (Qadir, 1989: 34). Jauh sebelurn umat Islam dapat menaklukkan daerah-daerah di Timur Dekat, pada saat itu Suriah merupakan tempat bertemunya dua kekuasaan dunia, Romawi dan Persia. Atas dasar itu, bangsa Suriah disebut-sebut memainkan peran penting dalam penyebaran kebudayaan Yunani ke Timur dan Barat. Di kalahgan umat Kristen Suriah, terutama kaum Nestorian, ihnu pengetahuan Yunani dipelajari dan disebarluaskan melalui sekolah-sekolah mereka. Walaupun tujuan utama sekolah-sekolah tersebut menyebarluaskan pengetahuan Injil, namun pengetahuan ilmiah, seperti kedokteran, banyak diminati oleh para pelajar. Sayangnya, pihak gereja memandang ilmu kedokteran itu sebagai ihnu sekular dan dengan demikian posisinya lebih rendah dari pada ilmu pengobatan spiritual yang merupakan hak istimewa para pendeta (Qadir, 1989: 35).

Selain itu, pada masa. ini juga didapati pusat-pusat ilmu pengetahuan seperti Ariokh, Ephesus, clan Iskandariah, di mana. buku-buku Yunani Purba masih dibaca dan diterjemahkan ke dalam berbagai bahasa, terutama Siriani, bahkan setelah pusat-pusat itu ditaklukkan oleh umat Islam, pengaruh pemikiran Yunani tetap mendalam dan meluas. Pada masa ini juga didapati seorang tokoh Kristen bernama Nestorius, yang melakukan dekontruksi atas pemaharnan teologi kalangan Kristen konservatif ortodoks, setelah ia terpengaruh oleh alam pikiran Yunani tersebut. Ia bersama pengikutnya kemudian hijrah ke Suriah dan melanjutkan kegiatan ilmu pengetahuan dan filsafat Yunani. Kegiatan ini pada gilirannya menghasilkan terjemahan karya filosof Yunam seperh 


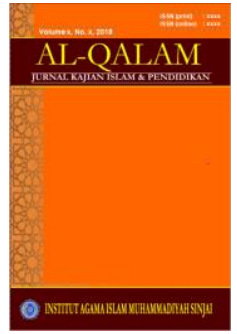

AL-QALAM

Jurnal Kajian Islam \& Pendidikan

Volume 11, No. 1, 2019

ISSN (print) : 1858-4152

ISSN (online) : 2715-5684

Homepage : http://journal.iaimsinjai.ac.id/index.php/al-qalam

Phorphyrius, di antaranya adalah Isagoge, Categories, Hermeneutica, dan Analytica Priori. Pusatpusat ilmu pengetahuan yang dipimpin oleh umat Kristen ini, terus berkembang dengan bebasnya sampai mereka berada di bawah kekuasaan Islam. Hal ini menunjukkan bahwa Islam tidak hanya mendukung adanya kebebasan intelektual, tetapi juga membuktikan. kecintaan umat Islam terhadap ihnu pengetahuan dan sikap hormat mereka kepada ilmuwan, tanpa memandang agama mereka (Qadir, 1989: 35).

\subsection{Perkembangan Ilmu pada Masa Islam Klasik}

Sebagaimaha telah disinggung di atas bahwa pentingnya ilmu pengetahuan sangat ditekankan oleh Islam sejak awal, mulai masa Nabi sampai dengan Khulafa al-Rasyidun, pertumbuhan dan perkembangan ilmu berkembang dengan pesat seiring dengan tantangan zaman.

Di masa Rasululah dan khulafaurrasiyidin ilmu pengetahuan peradaban berkembang, di berbagai bidang seperti pemerintahan, perindusrtian, ekonomi (transaksi/ Muarnalah), pendidikan, kesehatan dan lain-lain Raulullah di masa pernerintahan beliaulah kepala negara dari Daulah Islam yang berpusat di madinah. Dan setelah Beliau yaitu di masa sahabat berlaku system ke khilafahan. Sistem. pemerintahan Islam yang diwajibkan oleh Tuhan alam semesta adalah sistem. Khilafah. Di dalam sistem Khilafah inilah Khalifah diangkat metalui bailat berdasarkan Kitabullah dan Sunnah Raulullah untuk memerintah sesuai dangan wahyu Allah yang turunkan (Tahrir, 2006: 14). Karena itu, putuskanlah perkara di antara mereka menurut apa yang telah Allah turunkan ... QS. alMaidah(5): 48

Sesungguhnya Imam/Khalifah itu laksana perisai, tempat orang-orang berperang di belakanpya dan berlindunga kepadanya.(H.R. Muslim).

System Khilafah ini berbeda, dari system pernerintahan lainnya, system ini bukanlah system kemjaan, system kekaisaran, federasi, ataupun republick. Sesungguhnya struktur negara Khilafah berbeda dengan struktur semua sistern yang dikenal di dunia saat ini, meski ada kerniripan dalam sebagian penwnpakannya. Sumktur negara Khilafah diambil (ditetapkan) dari struktur negara yang ditegakkan oleh Rasulultah saw. di Madinah setelah Beliau hijrah ke Madinah dan mendirikan Daulah Islam di sana. Sftuktur negara Khilafah adalah sbuktur yang telah dijalankan oleh Yhulafaur Rasyidin setelah Fmulullah saw. Wafat (Tahrir, 2006: 20-29).

Dengan penelitian dan pendalarnan terhadap nash-nash yang berkaitan dengan suuktur negara itu, jelaslah bahwa sftuktur negara Khilafah dalmn bidang pernerintahan clan administrasinya adalah sebagai berikut: I . Khalifah, 2. Para Mu'6win at-Tafwfdh (Wuzard' atTafwfdh), 3. Wuzard'at-Tanfidz, 4. Para Wali, 5. Amir al-Jihdd, 6.Keamanan Dalarn Negeri, 7. Urusan Luar Negeri, 8. Industri, 9. Peradilan, 10. Mashdlih an-Nds (Kernaslahatan Urnum) 11. Baitul Mal, 12. Lembaga. Informasi, 13. Majelis Umat (SyUra dan MuhaSabah) (Tahrir, 2006: 29).

Rasulullah saw. pernah memerintahakan pendirian industri manjaniq (senjata pelontar) dan dababah (semacam tank dati kayu). Al-Baihaqi telah menyebutkan riwayat dalarn Sunan alBaihaqi dari Abu Ubaidah ra. Yana berkata: " Kernudian Rasulullah saw. Mengepung penduduk Thaif dan menggempurnya. dengan manjaniq selarna, 15 hari..." (Tahrir, 2006: 133-134). hal ini menenclakan perkembangan ilmu. di bidang industri terutarna, masalah persenjataan. Hal ini berdasar pada firman Allah SWT.:

Siapkanlah untuk menghadapi mereka kekuatan apa saja yang kalian sanggupi... Qs. alAnfal(8): 60

Dalam masalah pendidikan, Rasulullah saw. menetapkan tebusan orang-orang kafir yang menjadi tawanan perang Badar dengan mengajari 10 orang anak-anak kaum Muslim(membaca dan menulis). Hal ini menggantikan harta tebusan yang termasuk ghanimah dan menjadi milik kaum Muslim (Tahrir, 2006: 213). Dan sebagimana, diketahui bersama bahwa Al-Qur'an dan Sunnalah sebagai sumber ilmu, dan tidak hanya itu pun Al-Qur'an dapat juga menjadi obat bagi penyakit fisik atau psikis. Dalam al-Qur'an di jelaskan bahwa madu juga merupakan obat yang paling bagus. Dalam hadits-hadits Rasulullah saw. Menjelaskan tentang habba saudah yang mampu 
menyembuhkan segala macam penyakit kecuali maut, larangan mencapur makanan yang manis dan asin yang menjadi sumber penyakit, anjuran makan makanan yang halal lagi baik, makan bila lapar dan berhenti sebelum kenyang, anjuran menutup wadah air di malam hari karena Allah menurunkan penyakit pada malam haridan masih banyak yang lainya.

Dalam riwayat menurut Wadiyah Ibn Atha: "di madinah terdapatiga oang guru yang mengajar anak-anak, khalifah Umar memberikan nafkah kepada tiaptiap mereka lima belas dinar setiap bulan (63,75 g emas)." Dana ini diambil dari Baitul Mal (kas Negara. Demilianlag bukti atas perhatian para sahabat erhadap ilmu pengetahuan (Nadaa, 2005: 13-14).

Demikianlah sekelumit ilmu. pengetahuan di masa Rasulullah dan sahabat yang nyaris atau bahkan ingin dihapus, dari sejarah oleh sebagian para sejarawan yang tidak senang kepada Islam. Menjadikan kaum intelektual Muslim kekinian lebih mengenal peradaban duma barat karena adanya kebohongan dalam penulisan seJarah, di sampmg sebagian kaurn Muslim tidak tahu akan sejarah peraclabannya sendiri juga ada yang lebih bangga mempelajari ilmu dan peradaban barat dan merasa malu ketika mempelajari ilmu dan peradaban Islam, yang sebenarnya dijadikan inspirasi bagi ilmuwan Barat meraih kegemilangan ilmu penetahuannya yang diawali dengan masa Renaissan.

Selanjutnya, satu hal yang patut dicatat dalam kaitannya dengan., perkembangan ilmu dalam Islam adalah peristiwa Fitnah al-Kubra, yang ternyata tidak hanya membawa konsekuensi logis dari segi politis seperti yang dipahami selarna ini tapi ternyata juga membawa perubahan besar bagi pertumbuhan dan perkembangan ilmu di dunia. Islam. Pasca tedadinya Fitnah al-Kubra, muncul berbagai golongan yang memiliki aliran teologis tersendiri yang pada dasarnya berkembang karena alasan-alasan politis. Pada saat itu muncul aliran Syi'ah Yang membela, Ali, aliran Khawarij, dan kelompok Muawiyah. Namun, di luar konflik yang muncul pada saat itu, seJarah mencatat dua orang tokoh besar yang tidak ikut terlibat dalam. perdebatan teologis yang cenderung mengkafirkan satu sama lain, tetapi justru mencurahkan perhatiannya pada bidang ilmu agama. Kedua tokoh itu. adalah Abdullah Ibn Umar dan Abdullah Ibn Abbas. Yang disebut pertama Mencurahkan perhatiannya dalam bidang ilmu hadis, sementira yang disebut belakangan lebih berorientasi pada ilmu tafsir. Keduatokoh ini sering disebut sebagai pelopor turnbuhnya institusi keulamaan dalam Islam, sekaligus, berarti pelopor kaj ian mendalam dan sistematis tentang agama Islam. Mereka juga sering disebut seb11moyang" golongan Sunni atau Ahl-alSunnah wa ab Jama'ah (Madjid, 1997: 1-2).

Seperti sudah disinggung di atas, pasca Fitnah al-Kubra bermunculan berbagai aliran politik dan teologi,. Dari sini kemudian dapat dikatakan bahwa sejak awal Islam kajian kajian dalam bidang teologi sudah berkembang meskipun masih berbentuk embrio. Embrio inilah Yang pada masa kemudian menemukan bentuknya yang lebih sisternatis dalam. Kajian-kajian teologis dalam Islam (Madjid, 1997: 3). Sebagai contoh, persoalan tentang hukurn orang Yang berdosa besar; apakah mu!min atau kafir, msalah kebebasan atau ketidakbebasan manusia dalam menentukan perbuatannya, sudah diwakili sejak dini Perdebatan antara kalangan Mu!tazilah dan Khawarij. Dari sini tampaknya, seperd ditulis Nasution, (Nasution, 1982: 52-53). peranan akal dalam pergulatan pemikiran clan keilmuan dalarn tradisi Islam dimulai.

Tahap penting berikutnya dalam proses perkernbangan dan tradisi keilmuan Islam ialah masuknya unsur-unsur dari luar ke dalam Islam, khususnya unsur-unsur budaya PersoSemitik (Zoroastrianisme- khususnya Mazdaisme, serta Yahudi dan Kristen) dan budaya Hellenisme. Yang disebut belakangan mempunyai pengaruh besar terhadap pemikiran Islam ibarat pisau bermata. dua. Satu sisi ia mendukung Jabariyah (antara lain oleh Jahm Ibn' Safwan), sedang di sisi lain ia mendukung Qadariyah (antara lain Washil Ibn Atha' tokoh dan pendiri Mu'tazilah). Dari adanya pandangan yang dikotomis antara keduanya kemudian muncul. usaha menengahi dengan menggunakan argurnen-argumen Hellenisme, terutama filsafat Aristoteles. Sikap menengahi itu terutarna dilakukan oleh Abu At-Hasan AI-Asy'ari, dan Al-Maturidi yang juga menggunakan unsur Hellenisme (Nasution, 1982: 52-53). 


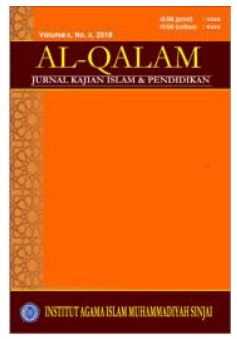

AL-QALAM

Jurnal Kajian Islam \& Pendidikan

Volume 11, No. 1, 2019

ISSN (print) : 1858-4152

ISSN (online) : 2715-5684

Homepage : http://journal.iaimsinjai.ac.id/index.php/al-qalam

Berdasarkan uraian di atas, dapat ditarik sebuah hipotesis sementara bahwa pada awal Islam pengaruh Hellenisme dan juga filsafat Yunani Terhadap tradisi keilmuan Islam sudah semakin kental, sehingga pada saat selanjutnya pengaruh itu pun terus mewarnai perkembangan ilmu pada masa berikutnya.

\subsection{Perkembangan Ilmu pada Masa Kejayaan Islam}

Pada masa kejayaan kekuasaan Islam, khususnya pada masa pernerintahan Dinasti Umayyah dan Dinasti Abbasiyah, Ilmu berkembang sangat maju dan pesat. Kemajuan ini membawa, Islam pada masa keemasannya, di mana pada saat yang sama wilayah-wilayah yang jauh di luar kekuasaan Islam masih berada pada masa kegelapan peradaban (Dark Age).

Dalam. sejarah Islam, kita mengenal nama-nama seperti Al-Mansur, Al-Ma!mun, dan Harun Ar-Rasyid, yang memberikan perhatian teramat besar bagi perkembangan ilmu. di dunia Islam. Pada masa pernerintahan Al-Mansur, misaInya, proses penerjemahan karya-karya filosof Yunani ke dalam bahasa Arab bez*an dengah pesat. Dikabarkan bahwa Al-Mansur telah memerintahkan pene emahan naskah-naskah Yunani mengenai filsafat dan ilmu, dengan memberikan imbalan yang besar kepada para ahli bahasa (penedemah). Pada masa Harun AIRasyid (786-809) proses pene emahan itu juga masih terus berlangsung. Harun memerintahkan,.Yuhanna. (Yahya) Ibn Masawayh (w. 857), seorang dokter Istana, untuk mene emahkan buku-buku kuno mengenai kedokteran. Di masa, itu juga dite emahkan karyakarya dalam bidang astronomi, seperti Siddhanta; sebuah risalah India yang dite ernahkan oleh Muhammad Ibn Ibrahim al-Fazari (w.. 806) (Nasution, 1970: 45). Pada masa selanjutnya oleh al Khawarizmi. Siddhanta ini dibuat versi baru te emahannya dan diberikan komentar-komentar (Nasution, 1970: 41). Selain itu juga ada Quadripartitus karya Purdemy, dan karya-karya bidang astrologi yang dite emahkan oleh satu tim sarjana (Qadir, 1989: 37-38).

Perkembangan ilmu selanjutnya berada pada masa pemerintahan AI-Ma!mun (813833). la adalah seorang pengikut Mu!tazilah dan seorang rasionalis yang berusaha memaksakan pandangannya kepada rakyat melalui mekanisme negara. Walaupun begitu, ia telah berjasa besar dalam. mengembangkan ilmu di dunia Islam dengan membangun Bait al-Hikmah, yang terdiri dari sebuah perpustakaan, sebuah observatorium, dan sebuah departemen pene emahan. Orang terpenting di Bait al-Hikmah adalah Hunain, seorang murid, Masawayh, yang telah berjasa menerjemahkan buku-buku Plato, Aristoteles, Galenus, Appolonuis, dan Archimedes. Selanjutnya pada pertengahan abad ke-10 muncul dua penerjemah terkemuka yaitu Yahya Ibn A'di,(w. 974), dan Abu Ali Isa Ibn Ishaq Ibn Zera (w. 1008). Yahya banyak mernperbaiki terjemahan dan menulis komentar mengenai karya-karya Aristoteles, seperti Categories, Sophist, Poetics, Metaphysics, dan karya Plato seperti Timaesus dan Laws. Yahya juga dikenal sebagai ahli logika dan menedemahkan The Prolegorpena of Ammonius dan sebuah kata pengantar untuk Isagogenya Pophyrius (Qadir, 1989: 39-40).

Selanjutnya, pada masa kejayaan ini, terdapat, juga tokoh- tokoh filsafat yang bergelut secara serius dalam. kajian-kajian di luar filsafat. Hal im bisa dipahami karena adanya kenyataan bahwa mereka menganggap ilmu-ilmu rasional sebagai bagian filsafat. Atas dasar inilah mereka memperlakukan persoalan persoalan fisika sebagaimana mereka memperlakukan masalah masalah yang bersifat metafisik. Salah satul bukti nyata dan mi adalah kitab al-Syifa, sebuah ensiklopedi filsafat Arab yang terbesar, yang berisi empat bagian. Bagian I mengenai logika, bagian II tentang fisika, bagian III tentang matematika, dan bagian IV membahas metafisika. Dalam bagian fisika, Ibn Sina ihnu-ihnu psikologi, zoologi, geologi, dan botani, dan pada bagian maternatika ia membahas geometri, ilmu hitung, astronomi, dan musik (Bahtiar, 2006: 120).

Selain tokoh di atas, kita juga mengenal Al-Kindi, seorang ilmuan yang lebih sering disebut saintis ketimbang filosof, yang berminat besar dalam bidang matematika dan fisika. la bahkan pemah berpendapat bahwa seseorang mungkin dapat menjadi filosof sebelum mempelajari filsafat. Tokoh lainnya adalah Al-Farabi yang mengadakan penelitian dalam bidang geometri dan mekanika, dan ia juga adalah seorang musikus muslim yang terbesar. Salah satu karyanya dalam 


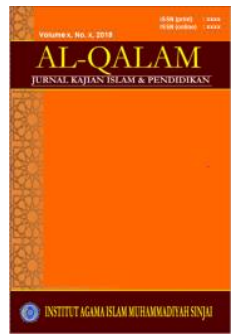

AL-QALAM

Jurnal Kajian Islam \& Pendidikan

Volume 11, No. 1, 2019

ISSN (print) : 1858-4152

ISSN (online) : 2715-5684

Homepage : http://journal.iaimsinjai.ac.id/index.php/al-qalam

bidang musik adalah Kitab al-Musiqi al-Kabir. Kemudian kita mengenal Ibn Bajah, Ibn Tufail, dan Ibn Ruslid, yang hidup di Andalusia dan bergelut secara intensif dalam bidang kedokteran. Ibn Rusyd, misalnya, mengarang al-Kulliyat yang diterjemahkan ke dalam bahasa Latin pada pertengahan abad ke-13 M. Selanjutnya ada Muhammad Ibnu Zakaria AI-Razi, dokter terbesar dalam Islam, bahkan di seluruh masa Abad Pertengahan. la terkenal karena orisinalitasnya dan pandangannya yang jernih dan kemampuannya menemukan jenis-jenis penyakit yang belum dikenal sebelumnya. Kitabnya yang berjudul al-Hawi adalah kitab yang paling terkemuka di antara karya-karya kedokteran Arab yang diambill manfaatnya oleh orang-orang Latin (Bahtiar, 2006: 42-43).

Sederetan nama yang penulis sebutkan di atas, hanya sebagian kecil saja dari para saintis dan juga filosof Muslim yang memberikan sumbangan tak ternilai. bagi kemajuan ilmu. Selain mereka tentu masih banyak tokoh-tokoh lain yang karena alasan pembatasan pembabasan, tiak dapat penulis sebutkan satu persatu. Selain adanya perkembangan ilmu yang dapat dikategorikan ke dalam bidang eksakta, matematika, fisika, kimia, geometri, dan lain sebagainya, sejarah juga mencatat kemajuan ilmu-ihnu keislaman, baik dalam bidang tafsir, hadis, fiqih, ushul fiqih, dan disiplin ihnu keislarnan yang lain. Perkembangan ilmu taffir dan'ulum Alquran belum menemukan bentuknya yang konkret sampai dengan abad ke-3 H (Abdullah, 2002: 25).

Dalam bidang hadis, perkembangan Ilmu hadis dimulai sejak Imam Syafi'i menyusun kitabnya. yang bernama ar-Risalah. Kitab ini mernuat problematika sanad dan rn-atan hadis, walaupun fidak demikian terperinci seperti y-ang dikemukakan oleh para ulama sesudahnya. Pada perkembangan selanjutnya ilmu hadis semakin dipertuas pembabasannya deengan mengambil dua bentuk., Pertama, ilmu. riwayah yattu suatu ilmu untuk mengetahu sabda, perbuatan, pengakuan dan Isifat Nabi Saw. dari segi ketepatan, pengutipan, peinbukuan, dan penieliharan penwayatan. Kedua, ilmu dirayah, yaitu ilmu yang membahas sanad dan matan dan segi diterima atau ditolaknya.suatu hadis, sehingga melahirkan kaidah yang berkaitan dengannya. Kitab yang berkaitan secara khusus dengan ilmu hadis muncul pada akhir abad ke-3, di antaranya kitab alMuhaddis al-Fasil bain arRawi wa al-Way karya ArRa-mahurmuzi. Kemudian pada abad, ke-4 menyusul. Al-Hakim An-Naisabun dengan karyanya Ma'rifah al-Num al-Hadis. Menyusul kemudian Al-Baghdadi derigan kitabnya al-Kifayahfi fim ar-Riwayah, pada, abad ke-5. iftnu hadis terus berkembang hingga mencapai puncaknya pada abad ke-7dengan munculnya kitab Muqaddimah ibn Salahfi Num al-Hadis, karya Ibn Shalah (Abdullah, 2002: 69).

Selain dalam bidang Alquran dan Hadis, ilmu fiqih dan ushul fiqih telah mengalami perjalanan panjang hingga tabentuk seperti sekarang ini.. Fiqih menjadi sebuah disiplin ilmu dengan mengalami beberapa tahapan. Pertama, tahap pembentukan pada masa, Rasulullah, Khulafa al-Rasyidun, hmgga paruh . pertarna abad ke- I H. Kedua, tahap pernbentukan fiqih yang dimulai pada paruh perUma abad ke-1 $\mathrm{H}$ hingga decade awal abad ke-2 $\mathrm{H}$. Pada tahap ini fiqih telah berbentuk mazhab.

Ketiga, tahap pematangan bentuk yang dimulai sejak decade awal abad ke-2 $\mathrm{H}$ hingga pertengahan abad ke-4 H. Pada masa ini ijtihad fiqih dikodifikasi dan. dilengkapi dengan ilmu ushul fiqih. Hal ini dapat terjadi atas perhatian yang diberikan Khalifa dalam pengembangan Ilmu pengetahuan. Sejak abad IV H. para Khalifah membangun berbagai perguruan tinggi yang dilengkapi dengan "iwan" (auditorium), asram mahasiswa, juga perumahan dosen dan ulama. Sealin itu pergurua tunggi tersebut juga dilengkapi taman-taman rekreasi, kamar mandi. Dapur, dan ruang makan (al-Jawi, 2007: 52).

Dalam sejarahnya yang sangat panjang Khilafah Islam tidak pernah mengadakan suatu ujian dalam lembaga-lembaga pendidikan negeri maupun swasta. Yang ada hanyalah ide pemberian "ijazah" sebagai pengganti dari ujian-ujian. apabila ada seorang siswa yang telah bertahun-tahun menekuni suatu ilmu, dan telah nampak penguasaannya atas ilmu tersebut, maka disebarkan pemberitahuan kepada siswa-siswa dan dewan guru. kcmudian diselenggarakan suatu sidang yang dihadiri oleh para ulama dan ilmuwan. Dalam sidang itu siswa yang telah Menyelesaikan suatu 


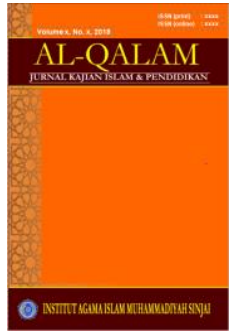

AL-QALAM

Jurnal Kajian Islam \& Pendidikan

Volume 11, No. 1, 2019

ISSN (print) : 1858-4152

ISSN (online) : 2715-5684

Homepage : http://journal.iaimsinjai.ac.id/index.php/al-qalam

mata pelajaran tertentu atau suatu kitab tertentu ditanyai mengenai ilmu yang ia tekuni. Apabila terlihat tanda kecakapan dan keistimewaan pada dirinya, ia diberikan hakhak yang membolehkannya melakukan perbuatan-perbuatan: (1) Mengajarkan ilmunya; (2) Meriwayatkan hadits Rasulullah SAW yang berasal dari guru-gurunya; (3) Rerfatwa; (4) Mengobati penyakit, bila ia sudah menguasai ilmu kedokteran; (5) Meracik obat-obatan; dan lain-lainnya sesuai dengan kepandaiannya (al-Baghdadi, 1996: 87).

Teknik munadborob (diskusi) atau ujian lisan mengenai suatu ilmu, seperti misalnya ilmu falak, syari'at, bahasa, dan lain-lain merupakan teknik yang paling sesuai untuk mengetahui sejauh mana kemampuan siswa dalam memahami pengetahuan yang ia pe-lajari. Sedangkan sistem ujian tulis akan mematikan daya cita dan kreatifitas siswa, dan pengadaan ujian tulis akan mendorong masyarakat hanya mengarahkan cita-citanya untuk mendapatkan predikat atau titel saja tanpa dilihat kemampuannya dalam mengajar, beijtihad, berfatwa, dan berkreasi (al-Baghdadi, 1996: 88).

Keempat, adalah tahap kemunduran fiqih yang ditandai oleh jatuhnya Baghdad ke bangsa Tartar dan tertutupnya pintu ijtihad oleh para ulama.seingga tidak ada yang mampu menggali hukum terhadap fenomena yang berkembang di kemudian hari. Sehinga setiap yang baru yang datangnya dari barat dianggap tidak layak diambil oleh ummat Islam.

\subsection{Masa Keruntuhan Tradisi Keilmuan dalam Islam}

Abad, ke-18 dalam sejarah Islam adalah abad yang paling menyedihkan bagi umat Islam dan memperoleh catatan buruk bagi peradaban Islam secara, universal. Sepertl yang diungkapkan oleh Lothrop Stoddard, bahwa menjelang abad ke-18, dunia Islam teiah merosot ke.tingkat yang terendah. Islam tampaknya sudah mati, dan yang tertinggal hanyalah cangkangnya yang kering kerontang berupa ritual tanpa $\mathrm{j}$ iwa dan takhayul yang merendahkan martabat umatnya. Ia, menyatakan seandainya Muhammad bisa kembali hidup, dia pasti akan mengutuk para pengikutnya: sebagai kaum murtad dan, musyrik (Qadir, 1989: 87).

Pemyataan Stoddard di atas menggambarkan begitu dahsyatnya proses kejatuhan peradaban dan tradisi keilmuan Islam yang kenfudian menjadikan umat Islam sebagai bangsa yang dijajah oleh bangsa-bangsa Barat. Runtuhnya bangunan tradisi keilmuan Islam secara garis besar dapat diterangkan karena adanya sebab-sebab berikut (Qadir, 1989: 87-88). alarn bukunya, The Reconstruction of . Religious Thought. in Islam lqbal meny atakan bahwa, salah satu penyebab utama kematian semangat ilmiah di kalangan umat Islam adalah diterimanya paham Yunani mengenai realitas yang pada pokoknya bersifat statis, sementara jiwa Islam adalah difiamis dan berkembang. Ia. Selanjutnya mengungkapkan bahwa semua aliran pemikiran Muslim bertemu dalarn suatu teori Ibn Miskawaih mengenai kehidupan sebagai suatu gerakan evolusi dan pandangan Ibn Khaldun mengenai sejarah (Bahtiar, 11465: 138).

Jika asumsi lqbal di atas bisa diterima, tepat apa yang dilukiskan oleh Amin Abdullah tentang sifat kedinamisan ilmu. ketika ia menyatakan menurut telaah filsafat ilmu, hampir semua jenis kegiatan ilmu, baik natural sciences maupun social sciences, bahkan religious sciences, selalu mengalami apa yang disebut.dengan shifting paradigm (pergeseran gugusan pernikiran keilmuan). Kegiatan ilmu selamanya bersifat historis, lantaran dibangun, dirancang, dan dirumuskan oleh akal budi manusia yang juga bersifat historis. Yang dimaksud bersifat historis adalah terikat ruang dan waktu, terpengaruh oleh perkembangan pemikiran dan perkembangan kehidupan social Yang mengitari penggal waktu ternentu. Dengan begitu, sangat dimungkinkan terjadinya perubahan, pergeseran, perbaikan, perumusan kembali, nasikh dan mansukh, serta rancang bangun epistemologi keilmuan.

Jika tidak demikian, maka. kegiatan keilmuan akan mandeg dengan sendirinya alias statis (Bahtiar, 11465: 49). Sebab lain Yang menyebabkan kehancuran tradisi keilmuan Islam adalah persepsi yang keliru dalam memahami pemikiran Al-Ghazali. Orang umumnya mengecam AIGhazali karena ia menolak filsafat seperti yang ia tulis dalarn Tahafu $t$ al- Falasifahnya. Padahal ia sebenamya menawarkan sebuah metode yang ilmiah dan rasional, dan juga menekankan 


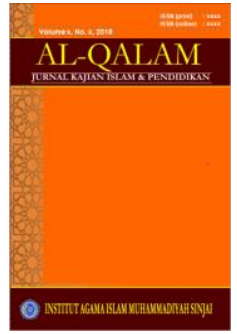

AL-QALAM

Jurnal Kajian Islam \& Pendidikan

Volume 11, No. 1, 2019

ISSN (print) : 1858-4152

ISSN (online) : 2715-5684

Homepage : http://journal.iaimsinjai.ac.id/index.php/al-qalam

pentingnya pengamatan dan analisis, serta sifat skeptis.Hal ini misalnya ia tuangkan dalarn karyanya berjudul al-Munqidz min sl-Dalal. Selain itu umat Islam.juga tidak memperhatikan karya Ibn Rusyhd (Tahafut al-Tahafut), , yang membela Aristotehanisme dan mengecam kritik.AlGhazali kepada filsafat. Seandainya orang mau meluangkan waktunya untuk mengkaji karya Ibn Rushd itu, barangkali kemerosotan rasional di kalangan umat Islam tidak akan separah sekarang ini.

Fiqih merupakan ilmu pertama yang dikembangkan oleh ummat Islam. Keempat sumbernya yang utarna yaitu Alquran, Sunnah, ljma' dan Qiyas, merupakan sumber hukum yang tetap. Namun karena sifatnya yan tetap itulah kaum Muslim harus menggunakan metode deduktif untuk sampai kepada keputusan mengenai masalah-masalah khusus, dan pada saat yang sama metode induktif kehilangah semangatnya. Di masa dekadensi, kegiatan intelektual sedang mencapai titiknya yang terendah, tidaklah mengherankan jika orang kemudian. menjadi bersikap dogmatis dan taklid secara membuta (Bahtiar, 11465: 138).

Para penguasa seringkali merasa takut dengan tersebar luasnya peodidikan, dan pengetahuan di kalangan massa yang dapat menggerogoti kekuasaan mereka yang mutlak. Munculnya orang-.orang yang pandai dan terampil,menyebabkan Ionggamya pengaruh golongan elit feodal dan keagamaan. Dengan membuka kesempatan, baru bagi masyarakat dan menawarkan cara yang baru sama sekali untuk memperoleh pengaruh melalul pengetahuan dan bukan melalui pewarisan, maka penyebarluasan ilmu dan teknologi menadikan dasar kekuasaan golongan yang mempunyai hak-hak istimewa. Selain sebab-sebab di atas, -kesulitan-kdsulitan ijtihad dan mistisisme asketik Juga merupakan faktor Yang menyebabkan kemunduran tradisi. intelektual dan keilmuan di dunia Islam (Bahtiar, 11465: 49).

Menurut Abdul Qadim Zallum sebab sebab kemerosotan Ummat Islam beberapa hal diantaranya yang paling menonjol:

(1) Transfer filsafat-filsafat India, Persia dan Yunani, serta adanya upaya sebagian kaurn muslimin untuk mengkompromikannya dengan Islam, walaupun terdapat perbedaan mendasar diantara keduanya.

(2) Adanya manipulasi ajaran Islam oleh orang-orang yang membenci Islam. Baik berupa ide-ide atau hukum hukum yang sebenarnya tidak bersumber dari Islam, dengan tujuan merusak citra Islam dan menjauhkan kaum muslimin dari Islam.

(3) Diabaikannya bahasa Arab dalarn memahami dan melaksanakan ajaran Islam, disusul kemudian dengan dipisahkannya dari Islam pada abad ketujuh Hijriyah..Padahal agama Islam tidak mungkin dapat dipahami tanpa bahasa Arab. Seperti misalnya dalam pengambilan hukum-hukum baru pada berbagai peristiwa yang berkembang, yang dilakukan dengan jalan ijtihad; ini tidak akan dapat dilakukan, tanpa menggunakan bahasa Arab.

(4) Serangan gelombang missionaris, dan serangan (orientalis) dalam bidang kebudayaan, menyusul serangan secara politis (yang mendominasi dunia Islam) dari negara negara kafir Barat, sejak abad ke-17 Masehi, dengan tujuan mengalihkan pandangan dan menjauhkan kaum muslimin dari Islam, yang pada akhimya untuk menghancurkan Islam (Zallum, t.t : 14).

\subsection{Beralihnya Ilmu Pengbetahuan ke Dunia Barat}

Masih berkaitan dengan era kejayaan keilmuan Islam, perlu juga disinggung secara sepintas tentang transformasi. ilmu dan duma Islam ke Barat. Terjadinya transformasi kebudayaan dan khususnya ilmu dari dunia Islam ke Barat disebabkan paling tidak oleh dua alasan. Pertama, kontak pribadi.. Setelah penalukan Arab atas Persia, Syam dan Mesir, orang orang Kristen di Timur mengadakan kontak dengan orang-orang Islam. Mereka hidup bersama dan menikmati toleransi agama yang besar. Mereka juga mengikuti kegiatan intelektual dan kebudayaan kaum Muslim yang mempunyai dokter-dokter, kimiawan, matematikus, dan para ahli astronom yang memberikan sumbangan khusus dalam penerjemahan warisan Yunani ke dalarn bahasa Arab (Bahtiar, 11465: 45). 


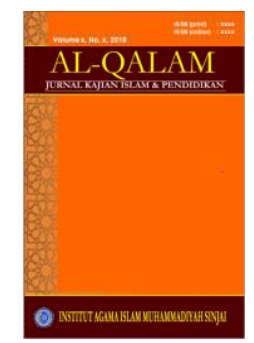

AL-QALAM

Jurnal Kajian Islam \& Pendidikan

Volume 11, No. 1, 2019

ISSN (print) : 1858-4152

ISSN (online) : 2715-5684

Homepage : http://journal.iaimsinjai.ac.id/index.php/al-qalam

Terjadinya peralihan ilmu pengetahuan dari Islam ke dunia Barat dapa dilahat dari beberapa factor berikut ini :

adanya pelajar-pelajar barat yang belajar di duinia Islam,seperti yang dilakukan oleh Raja Inggeris mengirim keluarganya untuk belajar di Negara Khilafah, seperti yang tampak dalam surat dari George II, Raja Inggeris, Swedia, Norwegia, kepada Khilafah Hisyam III diAdalusia Spanyol, kutipan surat tersebut antara lain:

" Kami mengharap anak-anak kami bisa menimba kagungan yangideal ini agar kelak menjadi cikal bakal kebaikan untuk mewaisi peninggalan yang Mulia guna memberi cahaya ilmu di negeri kami, yang masih diliputi kebodohan dari brbagai penjuru dunia." (Al-Wa'ie, 2007: 13).

Terjadinya kontak pribadi ini juga disebabkan karena.Byzantium secara geografis berdekatan dengan Dunia Islam. Dari sinilah kemudian gagasan-gagasan Barat masuk ke Dunia Islam dan uniknya gagasan-gagasan dari Dunia Islam masuk ke Barat, khususnya sesudah Perang Salib. Alasan yang lain, adanya kegiatan penerjemahan. Tidak dapat dipungkiri kebudayaan Islamlah yang mendorong orang-orang Latin melakukan penerjemahan. Setelah mengenal sebagian khazanah kebudayaan Islam mereka lalu. memperkaya pengetahuan mereka tentangnya. Mereka pernah mencoba menterjemahkan Alquran pada abad ke-10 Masehi. Namun, gerakan penterjemahan, yang sesungguhnya baru bermula pada abad ke-12. Toledo dan Palermo adalah dua pusat penerjemahan tersebar saat itu yang banyak mengoleksi sumber-sumber Arab berkat perantaraan orang Yahudi dan hubungan mereka dengan orangorang Kristen dan Islam (Abdullah, 2002: 102).

\section{Simpulan}

Simpulan dapat bersifat generalisasi temuan sesuai permasalahan penelitian, dapat pula berupa rekomendatif untuk langkah selanjutnya.

a) Proses penyampaian ilmu dan filsafat Yunani ke dunia Islam melalui proses penterjemahan penafsiran buku buku Yunani di negeri-negeri Arab dimulai jauh sebelum lahirnya agama. Islam.

b) Perkembangan ilmu pada masa klasik sangat maju karena prinsip-prinsip semua ilmu terdapat dalam Alquran dan Hadis; pencarian ilmu dalam segi apa pun pada akhirnya akan bermuara pada penegasan Tauhid. Tapi pada masa pemerintahan Ali Fitnah Besar menimpa kaum muslim memunculkan paham teologis, namun ada yang tidak melibatkan diri.dan merea adalah moyang Ahlussunnah Waljamaa'ah, kemudian masuklah unsur-unsur dari luar ke dalam Islam, seperti unsur-unsur budaya Perso-Semitik (Zoroastrianisme- khususnya Mazdaisme, serta Yahudi dan Kristen) dan budaya Hellenisme.

c) Pada masa kejayaan 3 dinasti besar Dinasti Umayyah dan Dinasti Abbasiyah, Fatimiyah Ilmu berkembang sangat maju dan pesat. Kemajuan ini membawa, Islam pada masa keemasannya, dengan kelahiran tokoh ilmuwan muslim di segala bidang.

d) Masa keruntuhan tradisi keilmuan dalam islam terjadi karena: a. Transfer filsafat-filsafat India, Persia dan Yunani, b. Adanya manipulasi ajaran Islam oleh orang-orang yang membenci Islam, c. Diabaikannya bahasa Arab menebakan sulit berijtihad, d. Serangan gelombang missionaris, dan serangan (orientalis) Serangan gelombang missionaris, dan serangan (orientalis).

e) Ilmu pengetahuan beralih ke dunia barat: a. adanya pelajar-pelajar barat yang belajar di duinia Islam, b. penterjemahan besar-besaran buku ke berbagai bahasa, c. perampasan ilmu-ilmu Islam dengan jalan perang salib. 


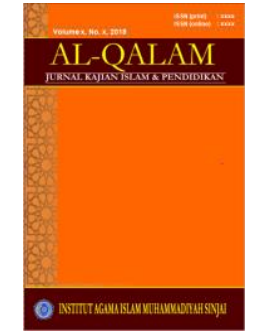

AL-QALAM

Jumal Kajian Islam \& Pendidikan

Volume 11, No. 1, 2019

ISSN (print) : 1858-4152

ISSN (online) : 2715-5684

Homepage : http://journal.iaimsinjai.ac.id/index.php/al-qalam

\section{Ucapan Terimakasih}

Bagian ini sifatnya pilihan, boleh tidak ada (optional). Ucapan terima kasih biasanya diberikan karena bantuan penulisan yang dipandang berpengaruh besar atau pun bantuan dana untuk melakukan penelitian.

\section{Daftar Pustaka}

Abdullah, Taufik (et. Al)., Ensiklopedi Temads dWa Islam. Jilid IV; Jakarta: Ictiar Baru Van Hove, 2002 "Al-Wa'ie", No. 86 Tahun VIII, 1-31 Oktober 2007.

Azra, Azyumardi, Pendidikan Islam: Tradisi dan Modernisasi Menuju Milenium Baru.Cet. 3; Jakarta: Kahinah, 2001

al-Baghdadi, Abdurrahman, Sistem Pendidikan di Masa Khilafa Islam; editor Nur Eva. Surabaya: Al-Izzah, 1996.

Bahtiar, Amsal, Filsafat IImu (Edisi. 3; Jakaita: PT. Raja Grafindo Persada, 2006

Departernen Agama R1, Al- Hikmah Al-Quran dan Terjemahannya. Cet. 10; Bandung: Diponegoro

al-Hasyimi, Ahmad, Mukhtar al- Hadits an-Nabawiyah. Cet. 12; Kairo: Syirkah Nur Asiya, t.t., h. 93.

Hizbut tahrir, Ajhizah al-Daulah Al-Khilaifah (Stuktur Negara Khilafah), penterjemah Yahya A.R.Cet.1; Jakarta: Hizbut Taluir Indonesia, 2006.

Shiddiq al-Jawi, Pembiayaan Pendidikan dalam Islam, ( Abdurrahman Muhammad Khalid, Soal Jawab Seputar Gerakan Islam), “ AlWa'ie” No. 81 TahunVII,(1-31 Mei 2007.

Madjid, Nur Cholis, Kaki Langit Peradaban Islam,(Cet. 1; Jakarta: Paramadina, 1997. Qatrun Nadaa, "Politik Pendidikan Islam ," El-Wa'ie, No. 59 Tahun V, 1-31 Juli 2005. Nasution, Harun, Akal dan Wahyu dalam Islam, (Cet.1; Jakarta: U1 Press, 1982.

Qadim Zallum, Abdul, Hizbut Tahrir, penerjemah Abu Afif Nurkhalis, Mengenal Sebuah Gerakan Islam di Timur Tengah Hizbut Tahrir. Jakarta: Al Khilafa, t.t.

Qadir CA, , Filsafat dan I1mu Pengetahuan dalam Islam, alih bahasa: Hasan Basari,(Edisi 1; Jakarta: Yayasan Obor Indonesia, 1989

Shihab, M.Quraish, Wawasan Al-Quran: Tairsir Maudul atas Berbagai Persoalan Umat, Cet. 12; Bandung: Mizan, 2001 